\title{
A NEW FACILE SYNTHESIS OF DIMETHYL 4-(2-(2,6-BIS(METHOXYCARBONYL)PYRIDIN-4-YL)VINYL) PYRIDINE-2,6-DICARBOXYLATE
}

\author{
Guoliang Gu, Ming Lu* \\ Chemical Engineering College, Nanjing University of Science and Technology, \\ Nanjing 210094, P.R. China \\ luming@mail.njust.edu.cn
}

\begin{abstract}
Anew facile synthesis of pyridine dicarboxylic acid derivative, dimethyl4-(2-(2,6-bis(methoxycarbonyl) pyridin-4-yl)vinyl)pyridine-2,6-dicarboxylate (DVDPA), from dimethyl 4-(chloromethyl)pyridine-2,6dicarboxylate (CMDPA) in presence of nitrogen bases has been described. The influences of different base/ CMDPA molar ratio and different nitrogen bases were also investigated. The result has shown that the yield could reach $81 \%$ when triethylamine was used and the molar ratio of base/CMDPA was 2.4. The overall yield of title compound via the three-step synthesis starting from dimethyl 4-(hydroxylmethyl)pyridine-2,6dicarboxylate (HMDPA) was improved to $69 \%$.
\end{abstract}

Key words: dimethyl 4-(2-(2,6-bis(methoxycarbonyl)pyridin-4-yl)vinyl)pyridine-2,6-dicarboxylate; pyridine dicarboxylic acid derivative; nitrogen base

\section{НОВА И ЕДНОСТАВНА СИНТЕЗА НА ДИМЕТИЛ 4-(2-(2,6-БИС(МЕТОКСИКАРБОНИЛ)ПИРИДИН-4- ИЛ)ВИНИЛ)ПИРИДИН-2,6-ДИКАРБОКСИЛАТ}

\begin{abstract}
Опишана е нова едноставна синтеза на дериват на пиридиндикарбоксилната киселина, диметил-4(2-(2,6-бис(метоксикарбонил)пиридин-4-ил)винил)пиридин-2,6-дикарбоксилат (DVDPA), со користење на диметил 4-(хлорометил)пиридин-2,6-дикарбоксилат (CMDPA) во присуство на азотни бази. Освен тоа, проучувано е влијанието на различен молски однос база/СMDPA и различните азотни бази. Резулатите покажаа дека приносот може да достигне 81 \% кога се користи триетиламин при молски однос база/ CMDPA од 2,4. Вкупниот принос на соединението е подобрен до 69 \% преку синтеза во три чекори поаѓајќ́ од диметил 4-(хидроксиметил)пиридин-2,6-дикарбоксилат (HMDPA).
\end{abstract}

Клучни зборови: диметил 4-(2-(2,6-бис(метоксикарбонил)пиридин-4-ил)винил)пиридин-2,6дикарбоксилат; дериват на пиридиндикарбоксилна киселина; азотна база.

\section{INTRODUCTION}

Our research group has recently been interested in synthesis of the pyridine dicarboxylic acid derivatives with rigid conjugated planar structure, which would be beneficial to the electronic negotiability [1], as many of them are useful in the field of fiber-optic telecommunications systems [2-5] and time-resolved fluoroimmunoassay (TR-FIA) [6, 7].
In recent years, increasing attention has been focused on organic reactions in aqueous media. Water is the most favorable solvent in terms of operating cost and environmental impact. The use of water as a solvent in organic synthesis is often surprisingly effective even for reactions that are traditionally carried out under anhydrous conditions. To the best of our knowledge the pyridine dicarboxylic acid derivative, DVDPA, has been reported only in our previous studies [8], 
which was synthesized by a Wittig reaction of corresponding alkyltriphenylphosphonium salts with aromatic aldehydes in $52 \%$ overall yield.

Herein we report the synthesis of DVDPA, which can be efficiently obtained from dimethyl 4-(chloromethyl)pyridine-2,6-dicarboxylate (CMDPA) in substantially improved conditions by using nitrogen bases in aqueous solution in place of alkyltriphenylphosphonium salts with aromatic aldehydes (Scheme 1) [9].

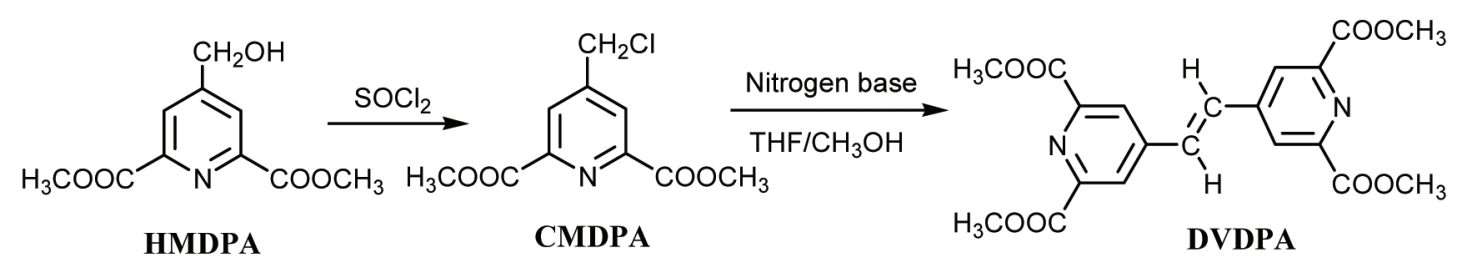

\section{Scheme 1}

\section{RESULTS AND DISCUSSION}

The starting dimethyl 4-(chloromethyl) pyridine-2,6-dicarboxylate was prepared by the chlorination of dimethyl 4-(hydroxylmethyl) pyridine-2,6-dicarboxylate (HMDPA) with sulfuryl dichloride (Scheme 1) [10]. The structure of CMDPA was confirmed by the spectra (MS, ${ }^{1} \mathrm{H}$ NMR) and elemental analysis. The ${ }^{1} \mathrm{H}$ NMR spectra revealed three characteristic singlets at 4.06, 4.45 and $8.27 \mathrm{ppm}$, assignable to $\mathrm{CH}_{3}, \mathrm{CH}_{2}$, and $\mathrm{C}_{6} \mathrm{H}_{2}$, respectively. Its mass spectrum showed the molecular ion peak at $\mathrm{m} / \mathrm{z} 243$, which indicated that the prepared compound was indeed HMDPA.

The influences of different nitrogen bases and the molar ratio of base/CMDPA on the product yield are shown in Table 1. When triethylamine was used and the molar ratio of triethylamine/ CMDPA was 2.4, the product yield reached the maximum. The proposed mechanism is shown in Scheme 2. The key factor for obtaining high yields may be attributed to the controlled availability of hydroxide ion. The $\mathrm{p} K_{\mathrm{b}}$ values of the amines are in the correct range, to generate sufficient concentration of $\mathrm{OH}^{-}$to deprotonate CMDPA and generate the anion INTER-CMDPA, and not to hydrolyze the esters present. Once the INTER-CMDPA is formed, it reacts with one molecule of CMDPA to give the desired DVDPA. The suggested mechanism is similar to the one reported by Gilbert P. Sollott [9].

Table 1

DVDPA from Nitrogen Bases and CMDPA

\begin{tabular}{ccc}
\hline \hline Nitrogen base & $\begin{array}{c}\text { Base/CMDPA } \\
\text { molar ratio }\end{array}$ & $\begin{array}{c}\text { DVDPA yield, } \\
\%\end{array}$ \\
\hline Ammonia & 1.6 & 58 \\
& 2.0 & 61 \\
& 2.4 & 65 \\
& 2.8 & 62 \\
\hline Dimethylamine & 1.6 & 46 \\
& 2.0 & 51 \\
& 2.4 & 55 \\
Diethylamine & 2.8 & 51 \\
\hline Triethylamine & 1.6 & 46 \\
& 2.0 & 51 \\
& 2.4 & 55 \\
& 2.8 & 51 \\
\hline Triethanolamine & 1.6 & 72 \\
& 2.0 & 74 \\
& 2.4 & 81 \\
& 2.8 & 76 \\
\hline & 2.6 & 5 \\
& 2.4 & 9 \\
& 2.8 & 12 \\
\hline
\end{tabular}

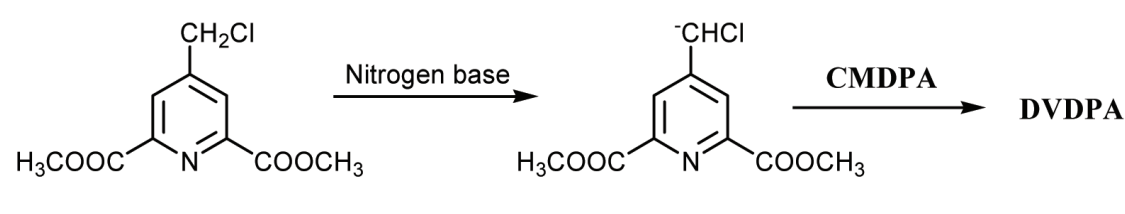

CMDPA

INTER-CMDPA

Scheme 2

Maced. J. Chem. Chem. Eng. 29 (2), 165-168 (2010) 
In aqueous THF and methanol in the presence of nitrogen bases, starting from CMDPA, the pyridine dicarboxylic acid derivative, DVDPA, was obtained (Scheme 1). The mass spectra of the product revealed the molecular ion peak at the expected $\mathrm{m} / \mathrm{z} 414$. The elemental analysis data was consistent with the expected molecular formula. In the infrar ed spectra (see Experimental section) strong and sharp bands at 1000 $\mathrm{cm}^{-1}$ appear which are assignable to $\delta(=\mathrm{C}-\mathrm{H})$, as well as the strong band at $1734 \mathrm{~cm}^{-1}$ assignable to the carbonyl group from the ester functional groups. The coupling constant obtained from the ${ }^{1} \mathrm{H}$ NMR spectrum of the proton $(\mathrm{Py}-\mathrm{CH}=)$ was $16 \mathrm{~Hz}$, which confirmed that DVDPA had trans configuration of the double bond.

The new facile synthetic route is simpler, more cost-effective and more eco-friendly than the previously reported procedure [9], with an overall yield increase from $52 \%$ to $69 \%$.

\section{EXPERIMENTAL}

Melting point was determined on a XR-4 apparatus and is uncorrected. IR spectra were recorded as $\mathrm{KBr}$ discs using an Avator-360-FT spectrum GX spectrophotometer. ${ }^{1} \mathrm{H}$ NMR spectra was recorded on a Bruker Advance RX300 analyzer in $\mathrm{CDCl}_{3}$ with TMS as internal standard $(400 \mathrm{~Hz})$. Mass spectra were recorded on GC-MS HP-5988 (EI mode, fused-silica capillary column). Elemental analyses were recorded on a Perkin Elmer 2400 elemental analyzer. 4-(Hydroxylmethyl)pyridine-2,6-dicarboxylate was synthesized according to the method by Ruiren Tang reported in the literature [11].

Dimethyl 4-(chloromethyl)pyridine-2,6dicarboxylate (CMDPA): To a solution of HMDPA (6.0 g, $26.5 \mathrm{mmol})$ in anhydrous chloroform (50 mL), sulfuryl dichloride $(4.8 \mathrm{~g}, 40.0 \mathrm{mmol})$ was added dropwise under nitrogen atmosphere at $-5^{\circ} \mathrm{C}$, then was stirred for about $40 \mathrm{~min}$. The solvent was removed under reduced pressure and the crude product was purified by recrystallization from ethanol to give a $5.9 \mathrm{~g}(86 \%)$ of flaxen solid. mp $168-170{ }^{\circ} \mathrm{C}$ (lit. [11] mp 168$\left.170{ }^{\circ} \mathrm{C}\right)$. IR (KBr), v/cm ${ }^{-1:} 3079,2959,2836$, 1725, 1710, 1380, 1257, 1125, 798. EI-MS, $\left(\mathrm{m} / \mathrm{z}\right.$, rel. intensity): $243\left(\mathrm{M}^{+}\right), 213\left(\mathrm{M}-\mathrm{OCH}_{3}\right.$, $62 \%), 184\left(\mathrm{M}-\mathrm{OCH}_{3}-\mathrm{CO}, 100 \%\right) .{ }^{1} \mathrm{H}$ NMR (400 MHz, $\mathrm{CDCl}_{3}$ ), $\delta: 8.27$ (s, 2H, Py-H), 4.45 (s, 2H, $\left.\mathrm{CH}_{2} \mathrm{Cl}\right), 4.06$ (s, 6H, $\mathrm{OCH}_{3}$ ). EA (calculated/found for $\mathrm{C}_{9} \mathrm{H}_{10} \mathrm{O}_{5} \mathrm{~N}$ ): \% C 49.53 (49.18), H 4.17 (4.23), N 5.61 (5.37).

Dimethlyl 4-(2-(2,6-bis(methoxycarbonylpyridin-4-yl)vinyl))pyridine-2,6-dicarboxylate (DVDPA): The reaction with triethylamine exemplify the general procedure which was used for all reactions summarized in Table 1. CMDPA (6.1 g, $25 \mathrm{mmol})$ was dissolved in THF (60 $\mathrm{mL})$ and methanol $(40 \mathrm{~mL})$ and to this mixture a $6.0 \mathrm{~g}$ triethylamine dissolved in methanol $(30 \mathrm{~mL})$ and water $(100 \mathrm{~mL})$ was added. The mixture was stirred for $15 \mathrm{~min}$, and then was heated to $50{ }^{\circ} \mathrm{C}$ with stirring for $60 \mathrm{~min}$. The reaction mixture was cooled to $10{ }^{\circ} \mathrm{C}$, was allowed to stand for about $30 \mathrm{~min}$, then it was filtered. The collected solid was recrystallised from methanol to give $4.2 \mathrm{~g}(81 \%)$ of DVDPA as a whitish solid. mp $192-194{ }^{\circ} \mathrm{C}$ (lit. [11] mp 191-193 $\left.{ }^{\circ} \mathrm{C}\right)$. IR (KBr), $v / \mathrm{cm}^{-1}: 3415,2918$, 1734, 1636, 1593, 1437, 1390, 1228, 1000, 911, 773, 696. ${ }^{1} \mathrm{H}$ NMR $\left(\mathrm{CDCl}_{3}\right), \delta: 7.16-7.53(\mathrm{~d}$, $2 \mathrm{H}, \mathrm{J}=16.0 \mathrm{~Hz}, \mathrm{Py}-\mathrm{CH}=), 8.13$ (s, 4H, Py-H), $4.04\left(\mathrm{~s}, 6 \mathrm{H}, \mathrm{OCH}_{3}\right)$. EA (calculated/found for $\mathrm{C}_{20} \mathrm{H}_{18} \mathrm{~N}_{2} \mathrm{O}_{8}$ ): \% C 57.36 (57.97), $\mathrm{H} 4.68$ (4.35), N 6.32 (6.76).

\section{REFERENCES}

[1] Paul N.W., Synthesis and properties of a twistophane ion sensor: A new conjugated macrocyclic ligand for the spectroscopic detection of metal ions, J. Org. Chem., 66, 4170-4179 (2001).

[2] Y. Hasegawa, Y. Wada, S. Yanagida, Strategies for the design of luminescent lanthanide(III) complexes and their photonic applications, J. Photochem. Photobiol. C: Photochem. Rev., 5, 183-202 (2004).

[3] P. Gawryszewska, J. Sokolnicki, J. Legendziewicz, Photophysics and structure of selected lanthanide compounds. Coord. Chem. Rev., 249, 2489-2509 (2005). 
[4] I. Hemmila, V. Laitala, Progress in lanthanides as luminescent probes. J. Fluoresc., 15, 529-542 (2005).

[5] J. C. G. Bunzli, Benefiting from the unique properties of lanthanide ions. Acc. Chem. Res., 39, 53-61 (2006).

[6] M. Morita, D. Rau, M. Herren, Circularly polarized luminescence and enantiomeric energy transfer discrimination of chiral Tb(III)-Nd(III) EDDS and related complexes. J. Alloys Compd., 380, 260-267 (2004).

[7] J. Sokolnicki, J. Legendziewicz, G. Muller and J. P. Riehl, The luminescence, molecular and electronic structure, and excited state energetics of tris complexes of 4-phenylethynyl-2,6-pyridinedicarboxylic acid with $\mathrm{Eu}(\mathrm{III})$ and $\mathrm{Tb}(\mathrm{III})$ prepared in sol-gel, Opt. Mater., 27, 1529-1536 (2005).
[8] G. L Gu, R. R. Tang, Y. H. Zheng and X. M. Shi, Synthesis, characterization and fluorescence properties of novel pyridine dicarboxylic acid derivatives and corresponding Tb(III) complexes, Spectrochim. Acta. Part A., 71, 209-214 (2008).

[9] G. P. Sollott, Conversion of 2,4,6-trinitrobenzyl chloride to. $2,2^{\prime}, 4,4^{\prime}, 6,6^{\prime}$-hexanitrostilbene by nitrogen bases, J. Org. Chem., 47, 2471-2474 (1982)

[10] R. R. Tang, Y. H. Zheng, G.L Gu, Synthesis and fluorescence properties of $\mathrm{Tb}(\mathrm{III})$ complexes with pyridine-2,6-dicarboxylic acid derivatives, $J$. Cent. South Univ. Technol., 15, 599-605 (2008).

[11] R.R. Tang, Y. H. Zheng, Q. Zhao, Synthesis of Dimethyl 4-(hydroxymethyl)pyridine-2, 6-dicarboxylate. Chem. React. Eng. Techno., 22, 83-85 (2006). 